\title{
sciendo
}

\section{FROM WASTE TO SUSTAINABLE FEED MATERIAL: THE EFFECT OF HERMETIA ILLUCENS OIL ON THE GROWTH PERFORMANCE, NUTRIENT DIGESTIBILITY, AND GASTROINTESTINAL TRACT MORPHOMETRY OF BROILER CHICKENS*}

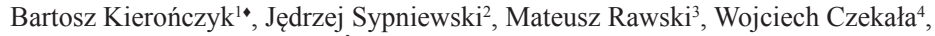 \\ Sylwester Świątkiewicz ${ }^{5}$, Damian Józefiak ${ }^{1,2}$ \\ ${ }^{1}$ Department of Animal Nutrition, Poznań University of Life Sciences, Wołyńska 33, \\ 60-637 Poznań, Poland \\ ${ }^{2}$ PIAST GROUP Research and Development Center, 63-400 Lewkowiec 50A, Poland \\ ${ }^{3}$ Division of Inland Fisheries and Aquaculture, Institute of Zoology, \\ Poznań University of Life Sciences, Wojska Polskiego 71C, 60-625 Poznań, Poland \\ ${ }^{4}$ Institute of Biosystems Engineering, Poznań University of Life Sciences, \\ Wojska Polskiego 50, 60-627 Poznań, Poland \\ ${ }^{5}$ Department of Nutrition Physiology, National Research Institute of Animal Production, \\ 32-083 Balice n. Kraków, Poland \\ •Corresponding author: bartosz.kieronczyk@up.poznan.pl
}

\begin{abstract}
In the present study, the complete cycle of the preconsumer waste transition by black soldier fly larvae (BSFL) into sustainable raw material (dietary fat) for broiler chickens was examined. In two individual experiments, the effects of selected rearing medium made from various preconsumer wastes on the nutritive value and performance of BSFL were tested (1st trial). In the second experiment, partial $(25,50$, or $75 \%)$ or total replacement of soybean oil fed to broiler chickens by BSFL fat obtained via supercritical $\mathrm{CO}_{2}$ extraction from larvae from the 1st experiment was conducted. In the performance trial on birds, nutrient digestibility, selected gastrointestinal tract (GIT) segments, internal organ traits, and welfare status were also measured. In the first trial, 1-day-old BSFL were allotted to 5 treatments (8 replicates each). The following substrates were tested, i.e., wheat bran, carrots, cabbage, potatoes, and a mixture of the previously mentioned organic food wastes (equal ratio of each). In the second experiment, a total of 960 day-old female Ross 308 chicks were randomly assigned to 5 dietary treatments (16 replicates and 12 birds per
\end{abstract}

\footnotetext{
*This work was supported by several sources i.e., IN OIL project: An innovative method for bioconversion of by-products from food processing industry that was financed by the National Centre for Research and Development within the Lider VII Programme No. LIDER/5/0148/L-7/15/NCBR/2016; the funds of Poznań University of Life Sciences; TEAM TECH/2016-2/11-0026 project entitled: Insects as novel protein sources for fish and poultry, financed by Foundation of Polish Science (POIR 4.4); as well as funds of the National Centre for Research and Development, no POIR.01.01.01-00-0828/15, entitled: InnSecta: innovative technology of feedstuffs production based on insect biomass.
} 
replicate). The following groups were applied: SO - $100 \%$ soybean oil, HI25 - a mixture containing 25\% BSFL fat and 75\% SO, HI50 - addition of BSFL and SO in a 50:50 ratio, HI75 a mixture containing $75 \%$ BSFL fat and $25 \%$ SO, and HI100 - 100\% BSFL fat. The results of the present study showed high variability in the chemical composition of insects among groups (410 vs. $550 \mathrm{~g} \mathrm{~kg}^{-1} \mathrm{CP}$; $60 \mathrm{vs.} 170 \mathrm{~g} \mathrm{~kg}^{-1} \mathrm{EE}$ ), as well as a significant influence of rearing substrate composition on BSFL performance, i.e., the average mass of 100 randomly chosen larvae $(P<0.001)$, waste reduction rate $(\mathrm{P}<0.001)$, and conversion rate $(\mathrm{P}=\mathbf{0 . 0 0 8})$. Moreover, the partial or total replacement of SO by BSFL fat did not affect $(\mathrm{P}>0.05)$ the growth performance, coefficients of apparent ileal digestibility of nutrients, selected organ weights and length, or the welfare status of the broilers. In conclusion, it is possible to obtain an environmentally friendly, sustainable energy source from BSFL biomass and implement it in broiler diets without a negative effect on the birds' production.

Key words: Hermetia illucens, black soldier fly, organic wastes, soybean oil, broiler chickens

Black soldier fly larvae (Diptera: Stratiomyidae, Hermetia illucens L. 1758; BSFL) are the most examined insect species used for organic waste management (Czekała, 2017; Mutafela et al., 2018), biofuel production (Nguyen et al., 2018 b), entomoremediation of polluted materials (Bulak et al., 2018), or even measurement of a human postmortem interval (Martínez-Sánchez et al., 2011). Furthermore, BSFL biomass is considered a novel ingredient in poultry (Józefiak et al., 2016), swine (Spranghers et al., 2018), rabbit (Dalle Zotte et al., 2018), fish (Nogales-Mérida et al., 2018), shrimp (Sánchez-Muros et al., 2018), and pet (Kierończyk et al., 2018 a) nutrition as a result of the high protein and fat content. Furthermore, the European Food Safety Authority (EFSA) claimed that BSFL is one of the most promising species that has potential as a food and feed (EFSA, 2015). Nevertheless, the European Parliament does not allow insects to be used for livestock production (Regulation (EC) No1069/2009), because insect meals are classified as processed animal protein (PAP). Additionally, PAP is forbidden for use in animal nutrition according to EU regulation (no. 999/2001), except for hydrolyzed proteins (Józefiak et al., 2016). Only in aquaculture and pet food production are invertebrates, including BSFL, permitted as a replacement, mainly fish meal, in pursuance of EU legislation (no. 2017/893). Currently, there are no legal recommendations regarding the use of insects' dietary fat in animal diets. In the available literature, limited data are shown in terms of fat extracted from H. illucens, which may be considered a novel energy source in fish, rabbit, and poultry nutrition (Li et al., 2016; Martins et al, 2018; Schiavone et al., 2017). These promising results have shown no negative effect on the growth performance, feed efficiency, carcass traits, GIT measurements, or nutrient deposition in fillets. In general, the quality of insects' fat is categorized between vegetable oil and animal fat origin products due to their fatty acid composition (Sosa and Fogliano, 2017). The range of fat content in BSFL biomass varies between 12\% and $38.6 \%$ of dry matter (DM) (De Marco et al., 2015; Spranghers et al., 2017). It should be mentioned that the lipid content is dependent on the insect development stage, and the chemical composition of the rearing substrate (Józefiak et al., 2016). Moreover, BSFL fat has largely been used for biodiesel production (Manzano-Agugliaro et al., 2012). However, Schiavone et al. (2017) successfully used BSFL fat in broiler diets. The substitution $(50 \%$ or $100 \%)$ of soybean oil by BSFL fat resulted in no significant effect on the growth and postslaughter performance of the broilers. 
However, there is no information about the technique of fat extraction, which is crucial to obtaining pure oil without any contamination of animal origin (3rd category materials). Currently, only a few extraction methods have been used to obtain fat from various species of insects, i.e., cold, aqueous, Soxhlet and Fohl extractions, as well as mechanical pressing with different yields and qualities of the final product (Kroeckel et al., 2012). Purschke et al. (2017 a) suggest $\mathrm{CO}_{2}$ supercritical extraction as an efficient defatting method for Tenebrio molitor meal. Kierończyk et al. (2018 b) confirmed the positive effect of the abovementioned technique on fat extraction from Tenebrionidae, i.e, T. molitor, as well as Zophobas morio. Moreover, there is still a lack of data in terms of partial $(25 \%, 50 \%$, and $75 \%)$ or total replacement of soybean oil by BSFL fat obtained using supercritical extraction with $\mathrm{CO}_{2}$ and their effect on broiler chicken performance.

In terms of a circular economy, i.e., reduce, reuse, recycle, and renewable (4R), the EU Parliament (Directive no. 2008/98) indicates a priority to manage, reduce or improve the efficient resource use of wastes. Other regulations (Directive 94/62/EC) highlighted the necessity of the reduction of biodegradable waste going to landfills. Therefore, the current study was designed as two separate experiments on BSFL and broiler chickens to examine the complete cycle of preconsumer waste transition (according to the 4R strategy) by BSFL into sustainable raw material (fat) for broiler chickens. In the first trial on BSFL, selected rearing medium made from various preconsumer wastes on the nutritive value and performance of BSFL was examined. In the second experiment, the aim was to replace soybean oil with BSFL fat obtained by supercritical $\mathrm{CO}_{2}$ from the larvae reared in the first trial.

\section{Material and methods}

According to Polish law and the EU directive (no 2010/63/EU) the experiments conducted within the study do not require approval of the Local Ethical Committee for Experiments on Animals in Poznań.

\section{Insects' experiment}

1-day-old BSFL were purchased from commercial sources (HiProMine S.A, Poland) and allotted to 5 treatments with 8 replicates each (random block). The following substrates were tested for their effects on the growth performance and chemical composition of insects: wheat bran, carrots, cabbage, potatoes, and a mixture of the abovementioned organic food wastes (an equal ratio of each). During the trial, the average weight of 100 randomly chosen larvae (AvW, g) on days 1, 7, and 13 was measured. In addition, the waste reduction rate (WRR, \%), conversion rate $(\mathrm{CR}, \%)$, efficiency of conversion of digested food (ECD, $\mathrm{g} / \mathrm{g})$, and frass residue mass $(\mathrm{g})$ were determined. Each treatment was normalized in terms of dry matter (DM) content and established at the level of $25 \%$ using water (wheat bran group) or wheat bran (the rest of the treatments) to ensure the optimal moisture conditions for growth. Fresh vegetable waste was ground (1400 rpm/5 min; PSP-500, Redfox, Poland) and offered ad 
libitum to insects. Substrates were not contaminated by animal products in accordance with EC regulation (no 1069/09). Larvae were randomly placed into plastic boxes with dimensions of $28 \times 20 \times 12 \mathrm{~cm}$. At the beginning of the experiment, $100 \mathrm{~g}$ (fresh matter) of each substrate was given to larvae and successively added as needed during the whole experimental period. Containers were located in a random block design under controlled temperature and humidity conditions, which were established as follows: $28^{\circ} \mathrm{C}$ and $70 \%$. The experiment lasted 13 days until the first prepupae had appeared, and then the larvae were harvested by sieving the substrate and using tweezers. All collected larvae were washed and dried with paper towels to remove the substrate residue and frozen at $-80^{\circ} \mathrm{C}$ for further chemical analyses. Samples of each substrate were collected as well. The following parameters were analyzed: DM, crude protein (CP), ether extract (EE), crude ash (CA), crude fiber $(\mathrm{CF})$, and the fatty acid profile of insects' fat. The nutritive value of selected organic waste substrates is presented in Table 1.

Table 1. The chemical composition of selected food wastes $\left(\mathrm{g} \mathrm{kg}^{-1} \mathrm{DM}\right)$

\begin{tabular}{lcc|c|c}
\hline \multicolumn{1}{c}{ Substrate } & $\mathrm{CP}^{1}$ & $\mathrm{EE}^{2}$ & $\mathrm{CA}^{3}$ & $\mathrm{CF}^{4}$ \\
\hline Wheat bran & 154.4 & 50.7 & 53.0 & 107.1 \\
Carrots & 134.0 & 18.9 & 60.0 & 100.8 \\
Cabbages & 132.4 & 56.7 & 53.8 & 91.6 \\
Potatoes & 125.6 & 8.0 & 48.7 & 69.9 \\
Mixture $^{5}$ & 130.8 & 13.0 & 57.5 & 87.3 \\
\hline
\end{tabular}

${ }^{1} \mathrm{CP}$ - crude protein; ${ }^{2} \mathrm{EE}$ - ether extract; ${ }^{3} \mathrm{CA}$ - crude ash; ${ }^{4} \mathrm{CF}$ - crude fiber; ${ }^{5}$ Mixture - a blend of each ingredient mixed at the same ratios.

\section{Insect fat composition}

The two oils (SO and HI) were obtained from commercial sources (Piast Pasze Sp. z o.o., Poland, and HiProMine S.A, Poland, respectively). The fatty acid composition of these fats is presented in Table 2. H. illucens larvae oil was obtained using supercritical $\mathrm{CO}_{2}$ extraction according to Jackowski et al. (2015) from insects fed a mixture of vegetable preconsumer wastes. Before extraction, the material was air-dried in an oven (SLN 240, POL-EKO Aparatura, Poland) for $24 \mathrm{~h}$ at $50^{\circ} \mathrm{C}$. The following parameters were used for the extraction: pressure -300 bar, temperature $-40^{\circ} \mathrm{C}$. For extract collection, a two-separator system was used. The $\mathrm{CO}_{2}$ flow was adjusted to $110.4 \mathrm{~kg} / \mathrm{h}$. Commercial $\mathrm{CO}_{2}$ (99\% purity, Zakłady Azotowe, Puławy, Poland) was used for the extraction.

\section{Broiler diets}

The composition of the broiler basal diet is shown in Table 3. Birds had ad libitum access to water and feed for 35 days. For each feeding period, all diets were calculated to meet the nutrient requirements recommended by the NRC (1994) for broiler chickens. The composition of the basal diet was designed according to Tancharoenrat et al. (2013) and was formulated on the basis of maize and soybean meal. The diets were prepared in mash form; all of the raw materials were ground by a disc mill (Skiold A/S, Denmark) at a $2.5 \mathrm{~mm}$ disc distance and mixed without heat 
treatment. The feed was produced in the Piast Pasze feed mill (Lewkowiec, Poland) according to ISO 9001:2008 procedures. The feed was prepared on a laboratoryscale line equipped with a horizontal double band mixer (Zuptor, Gostyń, Poland) with roller mills (Skiold, Sæby, Denmark). Starter diets were offered to all birds from 1 to $14 \mathrm{~d}$ of age, and grower-finisher diets were offered from 15 to $35 \mathrm{~d}$ of age. In the last $5 \mathrm{~d}(30-35 \mathrm{~d})$ of the experiment, $0.2 \%$ maize was replaced by $\mathrm{TiO}_{2}$ as an internal marker for the calculation of nutrient digestibility. No exogenous enzymes, such as carbohydrases, proteases, and phytases, were used in the study. Additionally, no ionophore coccidiostat was used in the feed. The following treatments were applied: SO - 100\% soybean oil, HI25 - a mixture containing 25\% BSFL fat and 75\% $\mathrm{SO}, \mathrm{HI} 50$ - a mixture of BSFL and soybean oils in a 50:50 ratio, HI75 - a mixture containing $75 \%$ BSFL fat and 25\% SO, and HI100 - 100\% BSFL fat.

Table 2. Fatty acid profiles of soybean oil, tested substrates (Subst.) and Hermetia illucens larvae (BSFL) dietary fat ( $\left.\mathrm{g} 100 \mathrm{~g}^{-1} \mathrm{FA}\right)$

\begin{tabular}{|c|c|c|c|c|c|c|c|c|c|c|c|}
\hline \multirow{2}{*}{ Item } & \multirow{2}{*}{$\mathrm{SO}^{1}$} & \multicolumn{2}{|c|}{ Wheat bran } & \multicolumn{2}{|c|}{ Carrots } & \multicolumn{2}{|c|}{ Cabbage } & \multicolumn{2}{|c|}{ Potatoes } & \multicolumn{2}{|c|}{ Mixture $^{2}$} \\
\hline & & subst. & BSFL & subst. & BSFL & subst. & BSFL & subst. & BSFL & subst. & BSFL \\
\hline 1 & 2 & 3 & 4 & 5 & 6 & 7 & 8 & 9 & 10 & 11 & 12 \\
\hline \multicolumn{12}{|c|}{ Saturated fatty acids } \\
\hline C8:0 Caprylic & 0.1 & $<0.1$ & $<0.1$ & $<0.1$ & $<0.1$ & $<0.1$ & $<0.1$ & $<0.1$ & $<0.1$ & $<0.1$ & $<0.1$ \\
\hline C10:0 Capric & 0.1 & $<0.1$ & 0.6 & $<0.1$ & 1.0 & $<0.1$ & 1.4 & $<0.1$ & 0.9 & $<0.1$ & 1.3 \\
\hline C12:0 Lauric & - & 0.2 & 26.0 & $<0.1$ & 37.9 & $<0.1$ & 40.1 & 0.1 & 33.9 & 0.8 & 42.1 \\
\hline C14:0 Myristic & 0.4 & 0.3 & 5.9 & 0.4 & 8.6 & 0.3 & 8.9 & 0.3 & 7.9 & 0.5 & 8.2 \\
\hline C16:0 Palmitic & 10.9 & 16.6 & 16.9 & 17.1 & 13.7 & 16.9 & 14.2 & 20.4 & 16.2 & 18.7 & 13.2 \\
\hline C18:0 Stearic & 4.5 & 1.4 & 4.6 & 1.4 & 3.4 & 1.6 & 3.3 & 2.0 & 3.6 & 1.7 & 2.7 \\
\hline C20:0 Arachidic & 0.1 & 0.2 & 0.2 & 0.3 & 0.1 & 0.3 & 0.1 & 0.4 & 0.1 & 0.3 & $<0.1$ \\
\hline \multicolumn{12}{|c|}{ Monounsaturated fatty acids } \\
\hline C16:1 Palmitoleic & $<0.1$ & 0.3 & 4.2 & 0.3 & 4.3 & 0.4 & 4.4 & 0.3 & 6.2 & 0.5 & 4.3 \\
\hline C18:1 $c 9$ Oleic & 23.7 & 16.4 & 14.0 & 12.9 & 9.3 & 16.1 & 10.6 & 19 & 11.5 & 17.2 & 8.3 \\
\hline C18:1 $c 11$ Elaidic & 1.7 & $<0.1$ & 0.3 & $<0.1$ & 0.3 & $<0.1$ & 0.3 & $<0.1$ & 0.4 & $<0.1$ & 0.5 \\
\hline C20:1 Eicosenoic & 0.1 & 0.7 & $<0.1$ & 0.7 & $<0.1$ & 0.6 & $<0.1$ & 0.8 & $<0.1$ & 0.7 & $<0.1$ \\
\hline \multicolumn{12}{|c|}{ Polyunsaturated fatty acids } \\
\hline C18:2 c9c12 Linoleic, LA & 50.3 & 54.9 & 16.4 & 57.4 & 10.5 & 49.6 & 7.2 & 39.6 & 6.9 & 43.8 & 6.8 \\
\hline $\begin{array}{l}\text { C18:3 c9c12c15 } \\
\alpha \text {-Linolenic, LNA }\end{array}$ & 7.2 & 4.3 & 1.3 & 4.8 & 1.7 & 5.8 & 0.8 & 3.2 & 0.9 & 3.8 & 0.9 \\
\hline $\mathrm{SFAs}^{3}$ & 16.2 & 19.5 & 54.9 & 20.4 & 66.2 & 20.2 & 68.7 & 24.7 & 63.3 & 23.3 & 68.6 \\
\hline $\mathrm{UFAs}^{4}$ & 83.8 & 20.4 & 37.5 & 21.1 & 27.2 & 21.0 & 24.2 & 25.4 & 27.0 & 23.9 & 21.7 \\
\hline MUFAs $^{5}$ & 26.3 & 18.6 & 19.8 & 15.5 & 15.1 & 18.7 & 16.2 & 22.1 & 19.2 & 20.1 & 14.0 \\
\hline PUFAs $^{6}$ & 57.5 & 60.3 & 17.7 & 63.3 & 12.1 & 57.3 & 8.0 & 46.9 & 7.8 & 51.2 & 7.7 \\
\hline MCFAs $^{7}$ & 11.5 & 0.5 & 26.8 & 0.4 & 39.1 & 0.4 & 41.7 & 0.4 & 35.0 & 1.1 & 43.6 \\
\hline$n-6$ & 50.3 & 55.1 & 16.4 & 57.6 & 10.5 & 49.9 & 7.2 & 40.1 & 6.9 & 44.3 & 6.8 \\
\hline$n-3$ & 7.2 & 5.2 & 1.3 & 5.7 & 1.7 & 7.4 & 0.8 & 6.9 & 0.9 & 6.9 & 0.9 \\
\hline
\end{tabular}


Table 2 - contd.

\begin{tabular}{l|c|c|c|c|c|c|c|c|c|c|c}
\hline \multicolumn{1}{c|}{1} & 2 & 3 & 4 & 5 & 6 & 7 & 8 & 9 & 10 & 11 & 12 \\
\hline$n 6 / n 3$ & 7.1 & 10.7 & 12.6 & 10.1 & 6.2 & 6.7 & 9 & 5.8 & 7.7 & 6.4 & 7.6 \\
PUFAs/SFAs & 3.6 & 3.1 & 0.3 & 3.1 & 0.2 & 2.8 & 0.1 & 1.9 & 0.1 & 2.2 & 0.1 \\
Linolenic/Linoleic & 0.1 & 0.1 & 0.1 & 0.1 & 0.2 & 0.1 & 0.1 & 0.1 & 0.1 & 0.1 & 0.1 \\
\hline
\end{tabular}

${ }^{1} \mathrm{SO}$ - soybean oil; ${ }^{2}$ Mixture - combination of wheat bran, carrots, cabbage, and potatoes in equal ratios; ${ }^{3} \mathrm{SFAs}$ - saturated fatty acids; ${ }^{4} \mathrm{UFAs}$ - unsaturated fatty acids; ${ }^{5} \mathrm{MUFAs}$ - monounsaturated fatty acids; ${ }^{6} \mathrm{PUFAs}$ - polyunsaturated fatty acids; ${ }^{7} \mathrm{MCFAs}$ - medium-chain fatty acids.

Table 3. The composition of the experimental diets for broilers

\begin{tabular}{lr|c}
\hline \multicolumn{1}{c}{ Ingredient $\left(\mathrm{g} \mathrm{kg}^{-1}\right)$} & $1-14$ days & $14-35$ days \\
\hline Maize & 560.0 & 634.1 \\
Soybean meal & 364.3 & 285.7 \\
Soybean oil/Hermetia illucens fat & 33.4 & 49.2 \\
Dicalcium phosphate & 26.1 & 11.9 \\
Mineral-vitamin premix ${ }^{\mathrm{a}}$ & 3.0 & 3.0 \\
Limestone & 2.3 & 5.9 \\
Salt $(\mathrm{NaCl})$ & 2.7 & 2.5 \\
Sodium sulphate $\left(\mathrm{Na}_{2} \mathrm{SO}_{4}\right)$ & 1.4 & 1.1 \\
L-Lysine & 2.1 & 2.2 \\
DL-Methionine & 2.8 & 2.5 \\
Tryptophan & 0.5 & \\
L-Threonine & 1.0 & 1.6 \\
L-Valine & 0.4 & 0.4 \\
Titanium dioxide $\left(\mathrm{TiO}_{2}\right)$ & & 2.0 \\
Analyzed nutritive ${\text { value }\left(\mathrm{g} \mathrm{kg}^{-1}\right)}^{\text {ME }\left(\mathrm{MJ} \mathrm{kg}{ }^{-1}\right)}$ & & \\
Crude protein & 12.6 & 13.4 \\
Ether extract & 215.8 & 185.0 \\
Crude fiber & 59.4 & 76.7 \\
Ca & 26.5 & 25.1 \\
Lysine & 8.5 & 6.5 \\
Methionine + cysteine & 13.1 & 11.2 \\
\hline
\end{tabular}

aProvided the following per kilogram of diet: vitamin A - 11.166 IU; cholecalciferol - 2500 IU; vitamin E - $80 \mathrm{mg}$; menadione $-2.50 \mathrm{mg}$; vitamin $\mathrm{B}_{12}-0.02 \mathrm{mg}$; folic acid $-1.2 \mathrm{mg}$; choline $-379 \mathrm{mg}$; D-pantothenic acid $-12.5 \mathrm{mg}$; riboflavin $-7.0 \mathrm{mg}$; niacin $-41.7 \mathrm{mg}$; thiamine $-2.2 \mathrm{mg}$; biotin $-0.18 \mathrm{mg}$; pyridoxine $-4.0 \mathrm{mg}$; ethoxyquin - $0.09 \mathrm{mg} ; \mathrm{Mn}\left(\mathrm{MnO}_{2}\right)-73 \mathrm{mg} ; \mathrm{Zn}(\mathrm{ZnO})-55 \mathrm{mg} ; \mathrm{Fe}\left(\mathrm{FeSO}_{4}\right)-45 \mathrm{mg} ; \mathrm{Cu}\left(\mathrm{CuSO}_{4}\right)-20 \mathrm{mg}$; $\mathrm{I}\left(\mathrm{CaI}_{2} \mathrm{O}_{6}\right)-0.6 \mathrm{mg}$; and $\mathrm{Se}\left(\mathrm{Na}_{2} \mathrm{SeO}_{3}\right)-0.3 \mathrm{mg}$.

\section{Birds and housing}

A total of 960 day-old female Ross 308 chicks obtained from a commercial hatchery were randomly assigned (random block) to 5 dietary treatments. Each treatment had 16 replicates and 12 birds per replicate. The birds were kept in 80 floor 
pens $(1 \mathrm{~m} \times 1 \mathrm{~m})$ over $35 \mathrm{~d}$, with fresh straw used as litter. The density of the stock was established at 12 birds $/ \mathrm{m}^{2}$, i.e., 12 birds per replicate (for $35 \mathrm{~d}$ ). To simulate commercial production conditions, the experimental pens were surrounded by a commercial broiler flock of 9,000 birds of the same origin as those used in the experiments. The building was equipped with artificial, programmable lights, automatic electric heating and forced ventilation. The temperature inside the building was $32-33^{\circ} \mathrm{C}$ at the beginning of the test and was reduced by $2-3^{\circ} \mathrm{C}$ each week. On the 28 th day, the temperature was set at $21^{\circ} \mathrm{C}$ and was approximately $18^{\circ} \mathrm{C}$ at the end of the test.

\section{Data and sample collection}

In the broiler chicken trial, the following variables were determined on days 14, 21, 28 and 35: body weight gain (BWG), feed intake (FI) and feed conversion ratio (FCR). At day 35, two randomly chosen chicks from each replicate (32 birds per treatment) were sacrificed by cervical dislocation after electrical stunning to collect selected organs, as well as ileal digesta to determine coefficients of nutrient digestibility and apparent metabolizable energy. The digesta was gently squeezed from 32 individual birds and pooled for 4 birds ( 8 replicates per treatment), mixed directly in containers, and stored on dry ice for further lyophilization and chemical analyses. Furthermore, the selected immune organ weight in relation to body weight (BW) $(\%$ $\mathrm{BW}$ ), i.e., the spleen and bursa of Fabricius, as well as the weight relative to BW of selected gastrointestinal tract organs, i.e., the duodenum, jejunum, ileum, and caeca, and their lengths in relation to $\mathrm{BW}(\mathrm{cm} / \mathrm{kg} \mathrm{BW})$, were measured. Additionally, the mass of internal organs, i.e., the heart, liver, pancreas, proventriculus and gizzard, was also obtained. The jejunum was considered to begin at the duodenum and end at Meckel's diverticulum. The ileum was defined as the small intestinal segment caudal to Meckel's diverticulum. After dissection, the abovementioned organs were rinsed in sterile water, drained, weighed using a PS 600/C/2 laboratory scale (Radwag, Radom, Poland) and then measured. Additionally, at the end of the experiment (35 d), 32 randomly chosen birds from each group were subjected to 5-point footpad dermatitis (FPD) scoring according to the method described by Kapell et al. (2017). Concisely, footpads without any lesions were classified as 0 , those with lesions sized less than $25 \%$ of the plantar surface were scored as 1, those with lesions up to $50 \%$ of the plantar surface were categorized as 2 , lesions occupying $75 \%$ of the surface were scored as 3 , and severe lesions where more than $75 \%$ of the plantar surface was affected, were scored as 4 .

\section{Chemical analyses}

The DM, CP, EE, CA and CF content of selected samples were determined according to AOAC (2005) using the 934.01, 976.05, 920.39, 942.05, and 2002.04 methods, respectively. The DM content was measured using an ED-56 air dryer (Binder 9010-0333, Tuttlingen, Germany); CP concentration was determined by a Kjel-Foss Automatic 16210 (A/S N. Foss Electric, Denmark); EE was determined by a Soxtec System HT-1043 extraction unit (Foss Tecator, Denmark); CA was determined using a muffle furnace (LM Linn Electro Therm, Eschenfelden, Germany); and CF was determined by Fibertec 1020 (Foss apparatus, Denmark). For $\mathrm{TiO}_{2}$ 
analysis, the samples were prepared in accordance with Myers et al. (2004), and the concentration was estimated using the procedure described by Short et al. (1996). Gross energy (GE) was determined using an adiabatic bomb calorimeter (KL $12 \mathrm{Mn}$, Precyzja-Bit PPHU, Poland) standardized with benzoic acid.

\section{Calculations}

Productivity of BSFL, i.e., the WRR, CR, and ECD, was calculated according to Diener et al. (2009). The selected variable was evaluated using the following formula:

$$
W R R=\frac{S-R}{S} \times 100 \%
$$

where $S$ is the total quantity of substrate provided and $R$ is the residue left after bioconversion (nondigested substrate + excretion products);

$$
C R=\frac{(W f-W I 0)}{S} \times 100 \%
$$

where $W f$ is the final biomass, WIO is the weight of larvae at the beginning of the trial, and $S$ is the total quantity of the substrate provided;

$$
E C D=\frac{B}{I-F}
$$

where $B$ is the assimilated feed (prepupal biomass), $I$ is the total feed offered to larvae, and $F$ is the residue.

The coefficients of ileal digestibility of $\mathrm{CP}$ and $\mathrm{EE}$ in broilers were calculated relative to the ratio of $\mathrm{TiO}_{2}$ (dietary marker) to determine the nutrient content in feed or digesta according to Kaczmarek et al. (2016). The following equation was used (crude protein digestibility calculation as an example):

$$
D_{\text {crudeprotein }}=1-\left[\left(\frac{\mathrm{TiO}_{2} \frac{\mathrm{g}}{\mathrm{kg}} \text { diet }}{\mathrm{TiO} \mathrm{2}_{\frac{\mathrm{g}}{\mathrm{kg}} \text { digesta }}}\right) \times\left(\frac{\text { crudeprotein }_{\frac{\mathrm{g}}{\mathrm{kg}} \text { digesta }}}{\text { crudeprotein }_{\frac{\mathrm{g}}{\mathrm{kg}} \text { diet }}}\right)\right]
$$

The $\mathrm{AME}_{\mathrm{N}}$ of experimental diets was calculated using the equation described below and was corrected to a zero nitrogen balance using $8.22 \mathrm{kcal} / \mathrm{g} N$ retained (Hill and Anderson, 1958).

$$
A M E_{N}=\left(G E_{\text {diet }}-\left[G E_{\text {digesta }} x \frac{T i O_{2 \text { diet }}}{T i O_{2 \text { digesta }}}\right]\right)-8.22 x\left(N_{\text {diet }}-\left[N_{\text {digesta }} x \frac{T i O_{2 \text { diet }}}{\text { TiO } 2_{\text {excreta }}}\right]\right)
$$

\section{Statistical analysis}

The experiments had a completely randomized design. In the first trial, the experimental unit was the box $(n=8)$. In the second trial, the unit was defined as an 
individual pen $(n=16)$ in the case of growth performance results; for the analyses of the coefficients of ileal digestibility of $\mathrm{CP}, \mathrm{EE}$, and $\mathrm{AME}_{\mathrm{N}}$ the pooled samples of digesta were defined as a unit $(n=8)$; additionally, in the case of organ weight and length, as well as FPD, the individual bird was claimed as a unit $(n=32)$. All data were preliminarily tested for normal distribution using the Kolmogorow-Smirnov test. An analysis of variance was conducted using Bartlett's test. The analyses were performed using SAS software (SAS Institute Inc., Cary, NC, USA). The significance of the differences among groups was determined with Duncan's multiple range test at the significance level of $\mathrm{P}<0.05$. In both experiments, the following general model was used:

$$
Y_{i}=\mu+\alpha_{i}+\delta_{i j}
$$

where:

$Y_{i}$ is the observed dependent variable,

$\mu$ is the overall mean,

$\alpha_{i}$ is the effect of selected medium for larvae rearing (exp. 1) or dietary fat source (exp. 2),

$\delta_{i j}$ is the random error.

\section{Results}

\section{Chemical composition of black soldier fly larvae}

The nutritive value of BSFL varied among treatments (Table 4). Differences were observed in the case of EE concentration, which remained in the range from $64.0 \mathrm{~g} \mathrm{~kg}^{-1}$ (wheat bran) to $173.5 \mathrm{~g} \mathrm{~kg}^{-1}$ (carrots). However, the CP level differed between groups by more than $130.0 \mathrm{~g} \mathrm{~kg}^{-1}\left(552.3 \mathrm{~g} \mathrm{~kg}^{-1}\right.$ vs. $\left.414.5 \mathrm{~g} \mathrm{~kg}^{-1}\right)$. Overall, the ash content of the BSFL biomass was high (with an average value equal to $\left.82.9 \mathrm{~g} \mathrm{~kg}^{-1}\right)$, with the highest and lowest levels exhibited by the wheat bran $\left(91.6 \mathrm{~g} \mathrm{~kg}^{-1}\right)$ and the potato groups $\left(73.2 \mathrm{~g} \mathrm{~kg}^{-1}\right)$, respectively. Wheat bran as a rearing medium for BSFL caused and increased level of CF, contrary to that of BSFL reared with potatoes.

Table 4. The chemical composition of Hermetia illucens larvae (BSFL) reared on food waste organic material used as a substrate $\left(\mathrm{g} \mathrm{kg}^{-1} \mathrm{DM}\right)$

\begin{tabular}{lr|r|r|r}
\hline \multicolumn{1}{c}{ Substrate } & $\mathrm{CP}^{1}$ & $\mathrm{EE}^{2}$ & $\mathrm{CA}^{3}$ & $\mathrm{CF}^{4}$ \\
\hline Wheat bran & 552.3 & 64.0 & 91.6 & 122.9 \\
Carrots & 472.0 & 173.5 & 82.4 & 108.4 \\
Cabbages & 493.1 & 159.9 & 85.7 & 99.2 \\
Potatoes & 414.5 & 77.5 & 73.2 & 83.3 \\
Mixture $^{5}$ & 453.8 & 140.0 & 81.6 & 98.3 \\
\hline
\end{tabular}

${ }^{1} \mathrm{CP}$ - crude protein; ${ }^{2} \mathrm{EE}$ - ether extract; ${ }^{3} \mathrm{CA}$ - crude ash; ${ }^{4} \mathrm{CF}$ - crude fiber; ${ }^{5}$ Mixture - the blend of each ingredient mixed at the same ratios. 


\section{Black soldier fly larvae performance}

The results of the selected BSFL production parameters are shown in Table 5. The lowest $\mathrm{AvW}$ of larvae growth at both 7 and $13 \mathrm{~d}$ of age was observed in the group with wheat bran used as a substrate $(\mathrm{P}<0.001)$. In contrast, the highest biomass (at 7 and 13 d) was observed in the group fed the vegetable mixture. No significant differences between treatments, i.e., carrots, cabbage, or the mixture were observed in terms of $\mathrm{AvW}$ (at $7 \mathrm{~d}$ of larvae age). The use of cabbage as a rearing medium increased $(\mathrm{P}<0.001)$ WRR levels, contrary to wheat bran and potatoes, which were characterized by a decreased worst reduction rate. Additionally, both cabbage, and a mixture of vegetable wastes improved $(\mathrm{P}=0.008) \mathrm{CR}$ levels, while this parameter decreased in other groups. In terms of ECD, there were no statistically significant differences among treatments $(\mathrm{P}=0.166)$. The highest amount of residue at the end of the experiment was observed in the group fed potatoes, contrary to the carrot and cabbage treatments, where the mass of frass was the lowest $(\mathrm{P}<0.001)$.

Table 5. Selected production parameters of Hermetia illucens larvae (BSFL) reared on food waste organic material used as a substrate

\begin{tabular}{l|c|c|c|c|c|c|c}
\hline & Wheat bran & Carrots & Cabbages & Potatoes & Mixture & RMSE $^{1}$ & P-value \\
\hline $\mathrm{AvW}^{2}(\mathrm{~g})$ & & & & & & \\
$1 \mathrm{~d}$ & 0.27 & 0.27 & 0.26 & 0.26 & 0.27 & 0.02 & 0.648 \\
$7 \mathrm{~d}$ & $3.32 \mathrm{c}$ & $5.60 \mathrm{a}$ & $5.24 \mathrm{a}$ & $4.47 \mathrm{~b}$ & $5.78 \mathrm{a}$ & 0.59 & $<0.001$ \\
$13 \mathrm{~d}$ & $5.12 \mathrm{c}$ & $9.96 \mathrm{~b}$ & $10.13 \mathrm{~b}$ & $8.82 \mathrm{~b}$ & $12.88 \mathrm{a}$ & 1.44 & $<0.001$ \\
$\mathrm{WRR}^{3}(\%)$ & $85.39 \mathrm{~d}$ & $94.18 \mathrm{~b}$ & $96.86 \mathrm{a}$ & $82.97 \mathrm{e}$ & $89.15 \mathrm{c}$ & 2.10 & $<0.001$ \\
$\mathrm{CR}^{4}(\%)$ & $10.17 \mathrm{c}$ & $10.89 \mathrm{bc}$ & $12.50 \mathrm{a}$ & $10.02 \mathrm{c}$ & $11.76 \mathrm{ab}$ & 1.49 & 0.008 \\
$\mathrm{ECD}^{5}(\mathrm{~g}: \mathrm{g})$ & 0.88 & 0.88 & 0.87 & 0.88 & 0.87 & 0.02 & 0.166 \\
Frass $(\mathrm{g})$ & $54.07 \mathrm{c}$ & $38.98 \mathrm{~d}$ & $21.04 \mathrm{e}$ & $114.13 \mathrm{a}$ & $72.71 \mathrm{~b}$ & 12.43 & $<0.001$ \\
\hline
\end{tabular}

$\mathrm{a}, \mathrm{b}-$ means within a column with no common letters differ significantly $(\mathrm{P}<0.05)$.

${ }^{1} \mathrm{RMSE}$ - root-mean-square error; ${ }^{2} \mathrm{AvW}$ - the average weight of 100 randomly chosen BSFL; ${ }^{3} \mathrm{WRR}$ - waste reduction rate; ${ }^{4} \mathrm{CR}$ - conversion rate; ${ }^{5} \mathrm{ECD}$ - efficiency of digested feed; the mean represents 8 experimental boxes.

\section{Fatty acid profile of black soldier fly larvae fat}

The fatty acid profiles of the investigated fat sources are summarized in Table 2. The fat extracted from BSFL was characterized by the highest value of saturated fatty acids (SFAs) in comparison to that of SO. The concentration of unsaturated fatty acids (UFAs), including mono- (MUFAs), and polyunsaturated fatty acids (PUFAs) determined in BSFL fat was lower in comparison to those of the SO fatty acid profile. The dominant fatty acids for both SO and BSFL fat were C16:0 (palmitic acid), C18:0 (stearic acid), C18:1 c9 (oleic acid), and C18:2 (linoleic acid). However, the BSFL fat was also characterized by a high level of C12:0 (lauric acid). Low omega- 6 and omega- 3 acid contents in the insect fat were observed; however, the ratio between n- 6 and n-3 was comparable between the evaluated fat sources. Only in the case of BSFL reared using wheat bran was its fat characterized by a high n-6 to n-3 ratio. Moreover, a low ratio between PUFAs and SFAs was observed in BSFL fat. 


\section{Broiler chicken growth performance}

The growth performance results of broilers are shown in Table 6. In the case of BWG in each treatment and period, no significant differences were noted $(\mathrm{P}>0.05)$. A decreased FI was observed only in the first two weeks of age (1-14 d) in birds fed with soybean oil replaced by BSFL fat diets in comparison to that of the SO control group $(\mathrm{P}<0.001)$. The lowest FI was observed in the HI100 treatment, and the partial inclusion of BSFL fat did not affect the FI between experimental groups. However, in the case of the whole trial period (1-35 d), there were no significant changes in FI. The FCR value was altered $(\mathrm{P}=0.031)$ by $\mathrm{BSFL}$ fat implementation in the first $14 \mathrm{~d}$, as well. The relatively high levels of BSFL fat in broiler chicken diets, i.e., 75\% and $100 \%$, resulted in a decrease of FCR compared to that of the control group (SO). However, no effect of BSFL fat inclusion on the FCR value in the whole experimental period was observed $(\mathrm{P}=0.748)$.

Table 6. The effect of soybean oil replacement with the fat obtained from Hermetia illucens larvae (BSFL) on the growth performance of broiler chickens (1-35 d)

\begin{tabular}{|c|c|c|c|c|c|c|c|}
\hline Item & $\mathrm{SO}^{1}$ & HI $25^{2}$ & $\mathrm{HI} 50^{3}$ & $\mathrm{HI} 75^{4}$ & HI $100^{5}$ & SEM $^{6}$ & $\mathrm{P}$-value \\
\hline \multicolumn{8}{|l|}{$\mathrm{BWG}^{7}(\mathrm{~g})$} \\
\hline $1-14 \mathrm{~d}$ & 493 & 486 & 484 & 491 & 480 & 15.43 & 0.110 \\
\hline $14-21 \mathrm{~d}$ & 526 & 514 & 507 & 507 & 511 & 21.64 & 0.100 \\
\hline $21-28 d$ & 696 & 689 & 690 & 695 & 687 & 25.58 & 0.818 \\
\hline $28-35 d$ & 704 & 714 & 724 & 727 & 722 & 86.11 & 0.947 \\
\hline $1-35 \mathrm{~d}$ & 2424 & 2399 & 2405 & 2420 & 2399 & 92.39 & 0.907 \\
\hline \multicolumn{8}{|l|}{$\mathrm{FI}^{8}(\mathrm{~g})$} \\
\hline $1-14 \mathrm{~d}$ & $621 \mathrm{a}$ & $608 \mathrm{~b}$ & $601 \mathrm{~b}$ & $601 \mathrm{~b}$ & $591 \mathrm{c}$ & 12.44 & $<0.001$ \\
\hline $14-21 \mathrm{~d}$ & 721 & 712 & 701 & 712 & 706 & 22.65 & 0.142 \\
\hline $21-28 d$ & 1031 & 1019 & 1010 & 1016 & 1017 & 29.82 & 0.361 \\
\hline $28-35 \mathrm{~d}$ & 1218 & 1200 & 1207 & 1217 & 1222 & 52.70 & 0.764 \\
\hline $1-35 \mathrm{~d}$ & 3593 & 3540 & 3525 & 3546 & 3536 & 85.08 & 0.207 \\
\hline \multicolumn{8}{|l|}{$\mathrm{FCR}^{9}(\mathrm{~g}: \mathrm{g})$} \\
\hline $1-14 \mathrm{~d}$ & $1.26 \mathrm{a}$ & $1.25 \mathrm{ab}$ & $1.24 \mathrm{abc}$ & $1.23 \mathrm{c}$ & $1.23 \mathrm{bc}$ & 0.03 & 0.031 \\
\hline $14-21 d$ & 1.37 & 1.39 & 1.38 & 1.41 & 1.38 & 0.04 & 0.233 \\
\hline $21-28 \mathrm{~d}$ & 1.48 & 1.48 & 1.47 & 1.46 & 1.48 & 0.04 & 0.364 \\
\hline $28-35 \mathrm{~d}$ & 1.74 & 1.70 & 1.68 & 1.69 & 1.73 & 0.17 & 0.832 \\
\hline $1-35 d$ & 1.48 & 1.48 & 1.47 & 1.47 & 1.48 & 0.04 & 0.748 \\
\hline FPD score ${ }^{10}$ & 1.69 & 1.41 & 1.53 & 1.50 & 1.47 & 0.80 & 0.695 \\
\hline
\end{tabular}

a, b - means within a column with no common letters differ significantly $(\mathrm{P}<0.05)$. ${ }^{1} \mathrm{SO}-100 \%$ of soybean oil; ${ }^{2} \mathrm{HI} 25$ - a mixture containing $25 \%$ BSFL fat and $75 \% \mathrm{SO} ;{ }^{3} \mathrm{HI} 50$ - a mixture of BSFL fat and soybean oil in a 50:50 ratio; ${ }^{4} \mathrm{HI} 75$ - a mixture containing 75\% BSFL fat and $25 \%$ SO; ${ }^{5} \mathrm{HI} 100-100 \%$ BSFL fat; ${ }^{6} \mathrm{SEM}$ - standard error of the mean; ${ }^{7} \mathrm{BWG}$ - body weight gain; ${ }^{8} \mathrm{FI}$ - feed intake; ${ }^{9} \mathrm{FCR}$ - feed conversion ratio; ${ }^{10} \mathrm{FPD}$ score -5 -point footpad dermatitis score; means represent 16 pens of 12 birds each (BWG, FI, FCR), or 32 individual birds (FPD). 
No significant differences $(\mathrm{P}=0.695)$ were noticed in the case of pododermatitis measurements, i.e., the FPD score as a welfare status.

\section{Broiler chicken ileal nutrient digestibility}

The effect of SO replacement with BSFL fat on the coefficients of apparent ileal digestibility of $\mathrm{CP}, \mathrm{EE}$, and $\mathrm{AME}_{\mathrm{N}}$ of broilers is presented in Table 7. No significant differences between groups were observed for the $\mathrm{CP}, \mathrm{EE}$, or $\mathrm{AME}_{\mathrm{N}}$ digestibility coefficients at the end of the trial $(35 \mathrm{~d})(\mathrm{P}>0.05)$.

Table 7. The effect of insect fat on the apparent ileal digestibility of crude protein, and the ether extract and apparent metabolizable energy corrected to a zero nitrogen balance $\mathrm{AME}_{\mathrm{N}}$ of broiler chickens (35 d)

\begin{tabular}{l|c|c|c|c|c|c|c}
\hline \multicolumn{1}{c|}{ Item } & $\mathrm{SO}^{1}$ & $\mathrm{HI}^{2}$ & $\mathrm{HI}^{3}$ & $\mathrm{HI}^{4}$ & $\mathrm{HI}^{2} 00^{5}$ & $\mathrm{SEM}^{6}$ & P-value $^{-}$ \\
\hline EE (\%) & 98.8 & 98.3 & 98.1 & 97.4 & 98.1 & 0.9 & 0.203 \\
$\mathrm{CP}(\%)$ & 84.0 & 84.2 & 84.5 & 84.1 & 83.0 & 2.2 & 0.854 \\
$\mathrm{AME}_{\mathrm{N}}$ (Kcal) & 3402 & 3424 & 3371 & 3432 & 3418 & 86 & 0.810 \\
\hline
\end{tabular}

${ }^{1} \mathrm{SO}-100 \%$ soybean oil; ${ }^{2} \mathrm{HI} 25$ - a mixture containing $25 \%$ BSFL fat and $75 \% \mathrm{SO} ;{ }^{3} \mathrm{HI} 50$ - a mixture of BSFL fat and soybean oil in a 50:50 ratio; ${ }^{4} \mathrm{HI} 75$ - a mixture containing $75 \%$ BSFL fat and 25\% SO; ${ }^{5} \mathrm{HI} 100-$ $100 \%$ BSFL fat; ${ }^{6} \mathrm{SEM}$ - standard error of the mean; ${ }^{7} \mathrm{EE}$ - ether extract; ${ }^{8} \mathrm{CP}$ - crude protein; ${ }^{9}$ apparent metabolizable energy corrected to a zero nitrogen balance; means represent 32 birds in 8 pooled replicates.

\section{Weights and lengths of selected organs}

The selected GIT and internal organ weights are represented in Table 8. Only in the case of the jejunum $(\mathrm{P}<0.001)$ and ileum $(\mathrm{P}<0.001)$ did the BSFL fat addition significantly decrease their weights in relation to those of the control group. Simultaneously, no significant differences among the treatments were recorded with respect to the lengths of selected GIT segments (Table 9).

Table 8. The effect of soybean oil replacement with the fat obtained from Hermetia illucens larvae (BSFL) on the weights of selected organs in relation to body weight (\% of BW)

\begin{tabular}{llllllllll}
\hline \multicolumn{1}{c}{ Item } & $\mathrm{SO}^{1}$ & $\mathrm{HI} 25^{2}$ & $\mathrm{HI} 50^{3}$ & $\mathrm{HI}^{4}$ & $\mathrm{HI}^{2} 00^{5}$ & $\mathrm{SEM}^{6}$ & P-value \\
\hline Duodenum & 0.70 & 0.73 & 0.67 & 0.68 & 0.66 & 0.09 & 0.165 \\
Jejunum & $1.24 \mathrm{a}$ & $1.15 \mathrm{ab}$ & $1.07 \mathrm{~b}$ & $1.10 \mathrm{~b}$ & $1.05 \mathrm{~b}$ & 0.14 & $<0.001$ \\
Ileum & $0.84 \mathrm{a}$ & $0.72 \mathrm{~b}$ & $0.66 \mathrm{~b}$ & $0.67 \mathrm{~b}$ & $0.64 \mathrm{~b}$ & 0.12 & $<0.001$ \\
Cecum & 0.14 & 0.14 & 0.16 & 0.14 & 0.13 & 0.03 & 0.124 \\
Proventriculus & 0.29 & 0.29 & 0.29 & 0.28 & 0.28 & 0.04 & 0.829 \\
Gizzard & 0.93 & 0.88 & 0.97 & 0.88 & 0.85 & 0.15 & 0.222 \\
Pancreas & 0.24 & 0.22 & 0.21 & 0.22 & 0.21 & 0.04 & 0.225 \\
Liver & 2.40 & 2.53 & 2.51 & 2.55 & 2.51 & 0.34 & 0.753 \\
Bursa of Fabricius & 0.14 & 0.12 & 0.13 & 0.13 & 0.12 & 0.05 & 0.634 \\
Spleen & 0.11 & 0.12 & 0.13 & 0.11 & 0.11 & 0.03 & 0.522 \\
Heart & 0.44 & 0.42 & 0.43 & 0.42 & 0.40 & 0.06 & 0.637 \\
\hline
\end{tabular}

$\mathrm{a}, \mathrm{b}$ - means within a column with no common letters differ significantly $(\mathrm{P}<0.05)$. ${ }^{1} \mathrm{SO}-100 \%$ soybean oil; ${ }^{2} \mathrm{HI} 25$ - a mixture containing $25 \%$ BSFL fat and 75\% SO; ${ }^{3} \mathrm{HI} 50$ - a mixture of BSFL fat and soybean oils in a 50:50 ratio; ${ }^{4} \mathrm{HI} 75$ - a mixture containing $75 \%$ BSFL fat and $25 \%$ SO; ${ }^{5} \mathrm{HI} 100$ - 100\% BSFL fat; ${ }^{6} \mathrm{SEM}$ - standard error of the mean; means represent 16 pens of 2 birds each $(n=32)$. 
Table 9. The effect of soybean oil replacement with the fat obtained from Hermetia illucens larvae (BSFL) on the length $(\mathrm{cm} / \mathrm{kg} \mathrm{BW})$ of selected sections of the gastrointestinal tract

\begin{tabular}{l|c|c|c|c|c|c|c}
\hline \multicolumn{1}{c|}{ Item } & $\mathrm{SO}^{1}$ & $\mathrm{HI} 25^{2}$ & $\mathrm{HI}^{3}$ & $\mathrm{HI}^{4}$ & $\mathrm{HI}^{3} 00^{5}$ & $\mathrm{SEM}^{6}$ & P-value \\
\hline Duodenum & 14.67 & 15.23 & 14.37 & 14.98 & 14.01 & 1.36 & 0.096 \\
Jejunum & 35.95 & 35.00 & 35.15 & 37.13 & 35.31 & 2.71 & 0.167 \\
Ileum & 33.46 & 31.71 & 31.81 & 33.32 & 33.01 & 4.06 & 0.594 \\
\hline
\end{tabular}

${ }^{1} \mathrm{SO}-100 \%$ soybean oil; ${ }^{2} \mathrm{HI} 25$ - a mixture containing $25 \%$ BSFL fat and $75 \%$ SO; ${ }^{3} \mathrm{HI} 50$ - a mixture of BSFL fat and soybean oils in a 50:50 ratio; ${ }^{4} \mathrm{HI} 75$ - a mixture containing 75\% BSFL fat and 25\% SO; ${ }^{5} \mathrm{HI} 100$ $100 \%$ BSFL fat; ${ }^{6} \mathrm{SEM}$ - standard error of the mean; means represent 16 pens of 2 birds each $(n=32)$.

\section{Discussion}

The chemical composition of insects considerably varies among species, as well as among the larvae development stage, e.g., fat content may range from $20 \%$ to 70\% (Coleoptera: Rhynchophorus phoenicis, larvae) or from 5\% to 14\% (Lepidoptera: Cirina forda, larvae) (Rumpold and Schlüter, 2013). Therefore, for nutritional purposes, insects' fat was extracted from a limited number of species, i.e., $H$. illucens (Schiavone et al., 2017), T. molitor (Purschke et al., 2017 a), Z. morio (Kierończyk et al., 2018 b), and Bombyx mori (Mentang et al., 2011). These studies focused on the insect species which is characterized by a high extracted fat yield, as well as their rearing large scale system is well elaborated. The impact of the production medium on fat content is well documented (Alifian et al., 2019; Dreassi et al., 2016; Jucker et al., 2017). The wide range of various organic waste products, e.g., rice straw, vegetables (a mixture of carrots, peas, salsify and celery), digestate from biogas fermentation, restaurant waste, a mixture of a middlings (cereals), dried distillers' grains with solubles (barley, corn, wheat and sugar syrup), and dried sugar beet pulp. were examined (Manurung et al., 2016; Spranghers et al., 2017; Tschirner and Simon, 2015). Additionally, poultry, swine, and cattle manure, and municipal wastes have been used as substrates for insects growth with positive environmental effects; however, EU regulations (no 1069/20097) state that the usage of these substrates as feed for insects intended for livestock nutrition is forbidden (EFSA, 2015; Newton et al., 2005). In the present study, the selection of various rearing media was connected to the Polish agricultural market, which produces significant amounts of potatoes, carrots, and cabbage. In 2017, Poland produced 9 million tonnes of potatoes (3rd place in the EU after Germany and France) and more than 0.8 million tonnes of carrots (2nd producer in the EU after the United Kingdom) (Eurostat, 2018); additionally, Poland is the leader producer of white cabbage in the EU, producing 1.2 million tonnes in 2017 (Kosson et al., 2017). The presented results confirmed the variability of the nutritive value of BSFL larvae, especially in the case of CP and EE content. The highest level of EE was determined in BSFL that were fed carrots, while the CP level was highest in those fed with wheat bran. In the available literature, the highest EE content of BSFL was obtained at 35\% (Newton et al., 2005) or even $40 \%$ (Meneguz et al., 2018). For the abovementioned reason, the composition of the rearing 
medium should be precisely balanced; otherwise, the addition of wheat bran, which is commonly used in insect nutrition, may decrease the EE concentration to $64.0 \mathrm{~g}$ $\mathrm{kg}^{-1}(\mathrm{DM})$. It should be stated that a substrate containing a high fiber value may cause malnutrition, which induced the usage of fat reserves in the larval body (Tschirner and Simon, 2015). Furthermore, the CP content (nitrogen-to-protein conversion factor, $\mathrm{N}$-factor $=6.25$ ) in BSFL varied in the scientific literature. The use of wheat bran as an exclusive diet in the present study resulted in $550 \mathrm{~g} \mathrm{~kg}^{-1}$ of CP (DM) in the BSFL biomass content. However, the CP concentration mostly ranges from 310 to $590 \mathrm{~g} \mathrm{~kg}^{-1}$ (DM) (De Marco et al., 2015; Jayaprakash et al., 2016; Józefiak et al., 2018; Kroeckel et al., 2012; Makkar et al., 2014; Nogales-Mérida et al., 2018). In general, fruit waste contributes to obtaining a low CP content in BSFL, in contrast to those reared with brewery byproducts (Meneguz et al., 2018) or organic waste streams of food designated for human consumption (Lock et al., 2016). However, it should be highlighted that during comparison of $\mathrm{CP}$ content, the N-factor, i.e., 6.25 or 4.67 , as well as the form of the BSFL, i.e., meal or defatted meal should be taken into consideration. The CA concentration in BSFL was high, and in the present study it ranged from 73.2 to $91.6 \mathrm{~g} \mathrm{~kg}^{-1}$ (DM). Fruit $\left(30 \mathrm{~g} \mathrm{~kg}^{-1}\right)$ and restaurant wastes $\left(27 \mathrm{~g} \mathrm{~kg}^{-1}\right)$ reduce CA content in comparison to winery byproducts $\left(103 \mathrm{~g} \mathrm{~kg}^{-1}\right)$ and digestate from biogas fermentation $\left(197 \mathrm{~g} \mathrm{~kg}^{-1}\right)$, which increase its value (Meneguz et al., 2018; Spranghers et al., 2017). However, the results of Spranghers et al. (2017) were in agreement with the present study in that a mixture of vegetable wastes may achieve approximately $96 \mathrm{~g} \mathrm{~kg}^{-1} \mathrm{CA}$ (DM). Interestingly, the CA content in BSFL could be much higher and reach up to $280 \mathrm{~g} \mathrm{~kg}^{-1}$, where $\mathrm{Ca}$ and $\mathrm{P}$ are the dominant elements (Makkar et al., 2014). The CF content in the present study was higher than that mentioned by Makkar et al. (2014), i.e., $70 \mathrm{~g} \mathrm{~kg}^{-1}$. It should be emphasized that from a practical point of view, only the mixture of vegetable waste was used in insect rearing; however, the possibility of eliminating some products should be evaluated to improve the final product, i.e., the invertebrate biomass nutritive value.

Furthermore, it is well documented that the composition of insect diets affects their production traits (Danieli et al., 2019; Rehman et al., 2017, 2019). Additionally, the levels of nutritional factors may cause significant differences in, e.g., the ECD value (Manurung et al., 2016). It should be highlighted that in the present study, no polluted materials were used, which could negatively influence the performance results (Purschke et al., 2017 b). The development time is also dependent on the diet and is crucial for profitability of the production. As Manurung et al. (2016) highlighted, the usage of rice stalk in various feeding rates may reduce the production time from $54 \mathrm{~d}$ to $38 \mathrm{~d}$. In comparison to the present study, where the first prepupae appeared at $\mathrm{d} 13$ (in the cabbage group), the reported production time of $38 \mathrm{~d}$ was much longer; however, it should be emphasized that the high concentration of lignin and cellulose in rice straw caused a reduced mass of larvae and prolonged their development in comparison to a mixture of rice straw with high energetic material, i.e., glucose and xylose (Li et al., 2015). In general, the development of larvae fed vegetables or chicken feed lasted from 12 to $15 \mathrm{~d}$, which is consistent with the authors' experience (Spranghers et al., 2017). In the available literature, only a mixture of organic wastes is examined as a rearing substrate for insect production, which makes 
individual ingredient comparison impossible at the moment. However, in general, the high concentrate feed in the case of nonfiber carbohydrates (NFC) caused BSFL body mass improvement, e.g., the digestate that contained the lowest value of NFC negatively altered the insect yield, in comparison to that of other groups (restaurant waste, chicken feed, and vegetables) (Spranghers et al., 2017). Diener et al. (2009) and Tschirner and Simon (2015) confirmed that substrates rich in carbohydrates and proteins may be converted efficiently by BSFL and consequently resulted in a high larvae weight, which is consistent with the current study, where the lowest AvW was observed in the wheat bran group. Simultaneously, contrary to Ziegler (2003), who claimed that the energy supply from proteins in insects is at a similar level to that of carbohydrates, the highest value of CP in wheat bran did not support the growth of BSFL. It could be concluded that not only the protein level but also the amino acids composition should be considered. It is well documented that potatoes contain antinutritive substances belonging to glycoalkaloids, i.e., $\alpha$-solanine and $\alpha$-chaconine, and exhibiting toxic activities. These substances may have insecticidal properties against pests, e.g, Empoasca fabae, Choristoneura fumiferana, and Trogoderma granarium (Bentley et al., 1984; Nenaah, 2011; Sanford et al., 1996). In the present study, a negative effect of potato substrate on BSFL was observed in the case of AvW (7 d of age); CR and WRR were also affected in comparison to those of larvae fed carrots, cabbage, and a mixture of organic waste. The value of WRR is strictly dependent on frass production. In the present study, the highest amount of residue was produced in the potato group, which was fed to BSFL as a raw material without any previous heat treatment. Nevertheless, insecticidal activity was not observed; however, the probable negative effect of the presence of glycoalkaloids on reducing the efficiency of substrate utilization and an increasing amount of frass was observed.

Contrary to St-Hilaire et al. (2007), who proved that it is possible to modify the fat and fatty acid content in insects' bodies, the results of the present study, as well as those of Woods et al. (2019), have shown that various substrates made from preconsumer organic wastes only partially affect the insect fat composition. The analyses of the fatty profile of the substrate had no impact on BSFL, which is in agreement with Spranghers et al. (2017) and exhibited the lack of relation between the fatty acid content in the vegetable substrates and insects. However, the general composition of BSFL fat changed between treatments. The lauric acid (C12:0) concentration as a dominant fatty acid in BSFL was not influenced by its level in the substrate; however, as Spranghers et al. (2017) mentioned, starch and other sugars may be involved in its synthesis. Moreover, in the current results, the lowest lauric acid value was observed in the wheat bran group as well as in potato group (high amount of starch), in contrast to that observed in BSFL fed with cabbage, where the content of C12:0, as well as of soluble sugars such as glucose, fructose, and sucrose, was higher. In general, the metabolism of insects is not dependent on substrate nutritional value, but the shift from lipogenesis to glycogenesis is related to the development stage, which requires the development of the fat reservoir (Inagaki and Yamashita, 1986). However, more data are needed in terms of the effect of increased lauric acid levels. Interestingly, the concentration of MCFAs in the BSFL fat is also not related to vegetable substrates. However, their concentration in the BSFL was high and compara- 
ble (Z. morio) or increased (T. molitor) in terms of that reported in other insect species considered as novel ingredients in animal diets (Kierończyk et al., 2018 b). It is well examined that both MCFAs and C12:0 have a significant impact on the microecology in the poultry GIT, as well as reduction of potentially pathogenic bacteria (Nguyen et al., 2018 a; Timbermont et al., 2010; Zeiger et al., 2017). This positive effect on GIT homeostasis, as well as on intestinal integrity, may cause a change in the status of insect ingredients as a functional feed; however, more data are still needed.

The fat extraction of insect biomass is not well elaborated, and the data are scarce. Most available scientific literature omit this crucial information. Only a few papers emphasized the usage of extraction methods, e.g., a cold-press technique (Li et al., 2016), mechanical pressing (Dumas et al., 2018), a method of soaking a filter bag in petroleum ether (Li et al., 2011 a), Soxhlet extraction (Abduh et al., 2017), the immersion of BSFL into petroleum ether at room temperature, the usage of petroleum ether with ultrasound ( $\mathrm{Li}$ et al., 2011 b), aqueous extraction (Tzompa-Sosa et al., 2019), solvent extraction using ethanol (99.5\%) (Zhao et al., 2016), hexane extraction (Purschke et al., 2017 a, 2018), and supercritical $\mathrm{CO}_{2}$ extraction (Kierończyk et al., 2018 b). Previous studies conducted by Kierończyk et al. (2018 b) and Purschke et al. (2017 a) confirmed the high efficiency of insect oil extraction from T. molitor, as well as $Z$. morio. Supercritical $\mathrm{CO}_{2}$ extraction is usually used in the food industry for decaffeination, fat and oil extraction, dealcoholization, aroma extraction, hop flavors extraction, colorant extraction, antioxidants extraction, and oil deacidification (Raventós et al., 2002). However, it should be emphasized that the abovementioned techniques were used primarily for the removal of fat from the insect meal to concentrate the CP content and to produce biodiesel fuel. Thus, further examination should be conducted in terms of the evaluation of various insect fat extraction methods on the yield and quality of the final product.

To date, only limited data have been published on the scope of BSFL fat inclusion in rat (Mentang et al., 2011), rabbit (Dalle Zotte et al., 2018), fish (Dumas et al., 2018), and poultry diets (Schiavone et al., 2017). However, partial (50\%) and total replacement of soybean oil by BSFL fat resulted in no negative changes in the growth performance of broiler chickens (Schiavone et al., 2017). Further investigation by Schiavone et al. (2018) confirmed their previously obtained results. In the present study, a significant FI decrease was observed during the first rearing period (1-14 d) in the insect fat addition treatment, without a negative effect on the FCR. However, only $75 \%$ and $100 \%$ SO replacement with BSFL fat positively reduced the FCR value. The limitation of feed intake up to $14 \mathrm{~d}$ of age cannot be related to a reduced effect on palatability of the used insect fat, as no changes in the FCR value, as well as no negative impact of feed choice, i.e., BSFL fat vs. SO, was observed (Schiavone et al., 2017). There were no significant differences between treatments over the whole experimental period (1-35 d). It should be highlighted that the similarity of fat of insects origin, in general, affects the growth performance and nutrient digestibility of commonly used energy sources such as soybean oil, palm oil or poultry fat (Benzertiha et al., 2019; Kierończyk et al., 2018 b). The obtained growth performance results corroborate the coefficients of apparent ileal digestibility of nutrients 
measured at $35 \mathrm{~d}$ of age. BSFL fat did not alter the $\mathrm{EE}, \mathrm{CP}$, or $\mathrm{AME}_{\mathrm{N}}$ digestibility of broilers in comparison to those of the SO control group.

The results of the measurements of selected GIT segments are also known to reflect the performance and digestibility. It is well known that poultry GIT morphometry reacts dynamically to nutrient availability in feed. The measurements of selected GIT weights and lengths are in agreement with those reported by De Verdal et al. (2010), where the birds with enhanced digestive efficiency were characterized by reduced GIT segment mass and length. In the scientific literature, there is no information about the negative impact of fats of insect origin on nutrient digestion. Both the partial and total replacement of commonly used energy sources with insect fat caused effectively no alterations or improved the efficiency of CP, CF and $\mathrm{AME}_{\mathrm{N}}$ digestion in chickens (Benzertiha et al., 2019; Kierończyk et al., 2018 b).

To conclude, the present study emphasized the possibility to manage, reduce, and efficiently use the resource of organic wastes for BSFL rearing as a sustainable source of nutrients for broiler chickens, according to EU regulations, i.e., Directive no. 2008/98, and no. 94/62/EC. Moreover, the presented results confirmed the high variability of insect nutritive value, which depends strictly on the rearing substrate quality, and that there is a significant effect of medium composition on BSFL performance. However, the BSFL fat extracted from larvae fed with organic preconsumer wastes (according to the circular economy strategy) used for the partial or total replacement of soybean oil in broiler diets may be used without any negative effect on the growth performance, the coefficients of apparent ileal digestibility of nutrients, as well as the GIT and selected internal organs.

The current work confirmed the possibility of eliminating soybean oil from broiler diets by implementing BSFL fat as a novel environmentally friendly raw material that reduces different preconsumer products. Nevertheless, further investigations should be carried out in terms of the effect of BSFL fat on the final product quality, which is crucial for future consumers.

\section{References}

Abduh M.Y., Jamilah M., Istiandari P., Manurung S., Manurung R. (2017). Bioconversion of rubber seeds to produce protein and oil-rich biomass using black soldier fly larva assisted by microbes. J. Entomol. Zool. Stud., 5: 591-597.

A 1 ifian M.D., Sholikin M.M., Evvyernie D., N ahrowi (2019). Potential fatty acid composition of Hermetia illucens oil reared on different substrates. Proc. 9th Annual Basic Science International Conference (BaSUC) IOP Conf. Series: Mat. Sci. Eng., 546: 062002.

AOAC (2005). Agricultural chemicals; contaminants; drugs. Official Methods of Analysis, vol. 1. AOAC, International, Gaithersburg, Maryland.

B entley M.D., Leonard D.E., Reynolds E.K., Leach S., Beck A.B., Murakoshi I. (1984). Lupine alkaloids as larval feeding deterrents for spruce budworm, Choristoneura fumiferana (Lepidoptera: Tortricidae). Ann. Entomol. Soc. Am., 77: 398-400.

B enzertiha A., Ki erończyk B., Rawski M., Kołodziejskie P., Bryszak M., Józe fi a k D. (2019). Insect oil as an alternative to palm oil and poultry fat in broiler chicken nutrition. Animals, 9: 116. 
Bulak P., Polakowski C., Nowak K., Waśko A., Wiącek D., B i eganowski A. (2018). Hermetia illucens as a new and promising species for use in entomoremediation. Sci. Total Environ., 633: 912-919.

C z e k a ła W. (2017). Concept of IN-OIL project based on bioconversion of by-products from food processing industry. J. Ecol. Eng., 18: 180-185.

Dalle Zotte A., Cullere M., Martins C., Alves S.P., Freire J.P.B., Falcão-e-Cunh a L., B e s s a R.J.B. (2018). Incorporation of Black Soldier Fly (Hermetia illucens L.) larvae fat or extruded linseed in diets of growing rabbits and their effects on meat quality traits including detailed fatty acid composition. Meat Sci., 146: 50-58.

Danieli P.P., Lussiana C., Gasco L., Amici A., Ronchi B. (2019). The effects of diet formulation on the yield, proximate composition, and fatty acid profile of the black soldier fly (Hermetia illucens L.) prepupae intended for animal feed. Animals, 9: 178.

De Marco M., Martinez S., Hernandez F., Madrid J., Gai F., Rotolo L., Belforti M., B ergero D., Katz H., D abbou S., Kovitvadhi A., Z oc carato I., G as co L., $\mathrm{Sch}$ i a vo ne A. (2015). Nutritional value of two insect larval meals (Tenebrio molitor and Hermetia illucens) for broiler chickens: apparent nutrient digestibility, apparent ileal amino acid digestibility and apparent metabolizable energy. Anim. Feed Sci. Tech., 209: 211-218.

De Verdal H., Mingnon-Grasteau S., Jeulin C., Le Bihan-Ducal E., Leconte M., M a ll t e S., M art in C., N a r c y A. (2010). Digestive tract measurements and histological adaptation in broiler lines divergently selected for digestive efficiency. Poultry Sci., 89: 1955-1961.

Di e n e r S., Z u r br üg g C., To c kn e r K. (2009). Conversion of organic material by black soldier fly larvae: establishing optimal feeding rates. Waste Manage. Res., 27: 603-610.

Dreassi E., Cito A., Zanfini A., Materozzi L., Botta M., Francardi V., (2016). Dietary fatty acids influence the growth and fatty acid composition of the yellow mealworm Tenebrio molitor (Coleoptera: Tenebrionidae). Lipids, 52: 285-294.

Dumas A., Ragg i T., B arkhous e J., Lew is E., Weltzien E. (2018). The oil fraction and partially defatted meal of black soldier fly larvae (Hermetia illucens) affect differently growth performance, feed efficiency, nutrient deposition, blood glucose and lipid digestibility of rainbow trout (Oncorhynchus mykiss). Aquaculture, 492: 24-34.

EFSA (2015). Scientific opinion on a risk profile related to production and consumption of insects as food and feed. EFSA J., 13: 4257-4317.

H i 11 F., A n d e r s o n D. (1958). Comparison of metabolizable energy and productive energy determinations with growing chicks. J. Nutr., 64: 587-603.

In a gaki S., Yamashita O. (1986). Metabolic shift from lipogenesis to glycogenesis in the last instar larval fat body of the silkworm, Bombyx mori. Insect Biochem.,16: 327-331.

J a ckowski J., Hurej M., Rój E., Poplonski J., Kosn y L., Hus zcza E. (2015). Antifeedant activity of xanthohumol and supercritical carbon dioxide extract of spent hops against stored product pests. B. Entomol. Res., 105: 456-461.

Jay a prakash G., S athiyabarathi M., Arokia-Robert M. (2016). Insects - a natural source for poultry nutrition. Int. J. Sci. Environ. Technol., 5: 733-736.

Józefiak A., Ki erończyk B., Rawski M., Mazurkiewicz J., Benzertiha A., Gobb i P., Nogales-Mérida S., Świątkiewicz S., Józefiak D. (2018). Full-fat insect meals as feed additive - the effect on broiler chicken growth performance and gastrointestinal tract microbiota. J. Anim. Feed Sci., 27: 131-139.

Józe fi a k D., Jó z e fi a k A., K i e rońc z y k B., R a w sk i M., Św ią t ki e wi c z S., D ł u g o s z J., E n g b e r g R.M. (2016). Insects - a natural nutrient source for poultry - a review. Ann. Anim. Sci., 16: $297-313$

Jucker C., Erba D., Le on ardi G.M., Lu u i D., S avoldelli S. (2017). Assessment of vegetable and fruit substrates as potential rearing media for Hermetia illucens (Diptera: Stratiomyidae) larvae. Environ. Entomol., 46: 1415-1423.

Kaczmarek S., Hejdysz M., Kubiś M., Kasprowicz-Potocka M., Rutkowski A. (2016). The nutritional value of yellow lupin (Lupinus luteus L.) for broilers. Anim. Feed Sci. Tech., 222: $43-53$.

Kapell D., Hocking P., Glover P., Kremer V., Ave nd a ñ S. (2017). Genetic basis of leg health and its relationship with body weight in purebred turkey lines. Poultry Sci., 96: 1553-1562. 
Ki erończyk B., Rawski M., Pawełczyk P., Różyńska J., Golusik J., Mikołajc zak Z., Józefiak D. (2018 a). Do insects smell attractive to dogs? A comparison of dog reactions to insects and commercial feed aromas - a preliminary study. Ann. Anim. Sci., 18: $795-800$.

Ki erończyk B., Raws ki M., Józefiak A., Mazurkiewicz J., Św iątkiewicz S., Si we k M., B ednarczyk M., Szumacher-Strabel M., Cieślak A., Benzertiha A., J ó ż e f i a k D. (2018 b). Effects of replacing soybean oil with selected insect fats on broilers. Anim. Feed Sci. Tech., 240: 170-183.

Kosson R., Felczyński K., Szwejda-Grzybowska J., Grzegorzewska M., Tucc i o L., Agati G., Kaniszewski S. (2017). Nutritive value of marketable heads and outer leaves of white head cabbage cultivated at different nitrogen rates. Acta Agr. Scand. Section B-S. P., 67: 524-533.

Kroeckel S., Harjes A.G.E., Roth I., Katz H., Wuertz S., Sus enbeth A., Schulz C. (2012). When a turbot catches a fly: Evaluation of a pre-pupae meal of the Black Soldier Fly (Hermetia illucens) as fish meal substitute - growth performance and chitin degradation in juvenile turbot (Psetta maxima). Aquaculture, 364: 345-352.

Li Q., Zheng L., Ca i H., Garza E., Yu Z., Z hou S. (2011 a). From organic waste to biodiesel: Black soldier fly, Hermetia illucens, makes it feasible. Fuel, 90: 1545-1548.

Li Q., Zheng L., Qi u N., Cai H., To mberlin J.K., Yu Z. (2011 b). Bioconversion of dairy manure by black soldier fly (Diptera: Stratiomyidae) for biodiesel and sugar production. Waste Manage., 31: 1316-1320.

L i S., J i H., Z h a n g B., T i a n J., Z h o u J., Y u H. (2016). Influence of black soldier fly (Hermetia illucens) larvae oil on growth performance, body composition, tissue fatty acid composition and lipid deposition in juvenile Jian carp (Cyprinus carpio var. Jian). Aquaculture, 465: 43-52.

Li W., Ming s un L., Zheng L., Li u Y., Zhang Y., Yu Z., Ma Z., Li Q. (2015). Simultaneous utilization of glucose and xylose for lipid accumulation in black soldier fly. Biotechnol. Biofuels, 8: 117.

L ock E.R., Arsiwalla T., Wa a g ø R. (2016). Insect larvae meal as an alternative source of nutrients in the diet of Atlantic salmon (Salmo salar) postsmolt. Aquacult. Nutr., 22: 1202-1213.

Mak k ar H.P., Tran G., H e uzé V., A n k ers P. (2014). State-of-the-art on use of insects as animal feed. Anim. Feed Sci. Tech., 197: 1-33.

Manurung R., Supriatna A., Esyanthi R.R., Putra R.E. (2016). Bioconversion of rice straw waste by black soldier fly larvae (Hermetia illucens L.): optimal feed rate for biomass production. J. Entomol. Zool. Stud., 4: 1036-1041.

Manzano-Agugliaro F., Sanchez-Muros M.J., Barroso F.G., Martínez-Sánchez A., R oj o S., Pérez - B a ñón C. (2012). Insects for biodiesel production. Renew. Sust. Energ. Rev., 16: 3744-3753.

Martínez-Sán chez A., Magana C., S a lon a M., Rojo S. (2011). First record of Hermetia illucens (Diptera: Stratiomyidae) on human corpses in Iberian Peninsula. Forensic Sci. Int., 206: e76-e78.

Martins C., Cullere M., Dalle Zotte A., Cardoso C., Alves S.P., Bess a R.J.B., Fre ir e J.P.B., F a l c ã o-e - C unh a L. (2018). Incorporation of two levels of black soldier fly (Hermetia illucens L.) larvae fat or extruded linseed in diets of growing rabbits: effects on growth performance and diet digestibility. Czech J. Anim. Sci., 63: 356-362.

Meneguz M., Schiavone A., Gai F., Dama A., Lussiana C., Renna M., Gasco L. (2018). Effect of rearing substrate on growth performance, waste reduction efficiency and chemical composition of black soldier fly (Hermetia illucens) larvae. J. Sci. Food Agr., 98: 5776-5784.

Mentang F., M a it a M., U s h i o H., O h s h i m a T. (2011). Efficacy of silkworm (Bombyx mori L.) chrysalis oil as a lipid source in adult Wistar rats. Food Chem., 127: 899-904.

Mut a fel a R.N., Mirat a M., A id G., Ols s on M., Hog l and W. (2018). Organic waste management via Hermetia illucens: a mini review. Linnaeus Eco-Tech. Proc. 11th International conference on establishment of cooperation between companies and institutions in the Nordic countries, the Baltic Sea region and the world, 19-21.11.2018, Kalmar.

Myers W., Ludden P., N a y ig i hug u V., Hes s B. (2004). Technical Note: A procedure for the preparation and quantitative analysis of samples for titanium dioxide. J. Anim. Sci., 82: 179-183. 
National Research Council (1994). Nutrient Requirements of Poultry. 9th Rev. Ed. National Academy Press. Washington DC. USA.

$\mathrm{N}$ e $\mathrm{n}$ a a h G. (2011). Individual and synergistic toxicity of solanaceous glycoalkaloids against two coleopteran stored-product insects. J. Pest Sci., 84: 77-86.

N e w t o n L., Sheppard C., Wat s o n D.W., B u rtle G., D ove R. (2005). Using the black soldier fly, Hermetia illucens, as a value-added tool for the management of swine manure. In: Animal and Poultry Waste Management Center, Williams M. (ed.). North Carolina State University, Raleigh, NC 17, pp. 1-17.

Nguyen D., Le e K., Moham madighe is ar M., Kim I. (2018 a). Evaluation of the blend of organic acids and medium-chain fatty acids in matrix coating as antibiotic growth promoter alternative on growth performance, nutrient digestibility, blood profiles, excreta microflora, and carcass quality in broilers. Poultry Sci., 97: 4351-4358.

Nguyen H.C., Liang S.H.L., Li S.Y., S u C.H., Chien C.C., Chen Y.J., Huong D.T.M. (2018 b). Direct transesterification of black soldier fly larvae (Hermetia illucens) for biodiesel production. J. Taiwan Inst. Chem. E., 85: 165-169.

Nogales-Mérida S., Gobbi P., Józefiak D., Mazurkiewicz J., Dudek K., Rawski M., Ki erończy k B., Jó ze fi a k A. (2018). Insect meals in fish nutrition. Rev. Aquacult., 1-24, doi: 10.1111/raq.12281.

Purschke B., S te g mann T., S chre in er M., Jäg e r H. (2017 a). Pilot-scale supercritical $\mathrm{CO}_{2}$ extraction of edible insect oil from Tenebrio molitor $\mathrm{L}$. larvae - Influence of extraction conditions on kinetics, defatting performance and compositional properties. Eur. J. Lipid Sci. Tech., 119: 1600134.

Purschke B., Scheibelberger R., Axmann S., Adler A., Jäger H. (2017 b). Impact of substrate contamination with mycotoxins, heavy metals and pesticides on the growth performance and composition of black soldier fly larvae (Hermetia illucens) for use in the feed and food value chain. Food Addit. Contam. A, 34: 1410-1420.

Purschke B., Tanzmeister H., Meinlschmidt P., Baumgartner S., Lauter K., Jäg e r H. (2018). Recovery of soluble proteins from migratory locust (Locusta migratoria) and characterisation of their compositional and techno-functional properties. Food Res. Int., 106: 271-279.

Raventós M., D u arte S., A l a r cón R. (2002). Application and possibilities of supercritical $\mathrm{CO}_{2}$ extraction in food processing industry: an overview. Rev. Agroquim. Tecnol., 8: 269-284.

Rehman K., Rehman A., Ca i M., Zheng L., Xi a o X., S a mroo A.A., Wang H., Li W., Yu Z., Z h ang J. (2017). Conversion of mixtures of dairy manure and soybean curd residue by black soldier fly larvae (Hermetia illucens L.). J. Clean. Prod., 154: 366-373.

Rehman K., Rehman R., Somroo A.A., Cai M., Zheng L., Xiao X., Rehman A., Rehman A., Tomberlin J.K., Yu Z., Zhand J. (2019). Enhanced bioconversion of dairy and chicken manure by the interaction of exogenous bacteria and black soldier fly larvae. J. Environ. Manage., 237: 75-83.

R u m p o ld B.A., S chlüt e r O.K. (2013). Potential and challenges of insects as an innovative source for food and feed production. Innov. Food Sci. Emerg., 17: 1-11.

Sánchez-Muros M.J., Renteria P., Vizcaino A., B arroso F.G. (2018). Innovative protein sources in shrimp (Litopenaeus vannamei) feeding. Rev. Aquacult., 1-18, doi.org/10.1111/ raq. 12312.

S a n ford L., D o m e k J., C a n te lo W., K o b a y a sh i R., S ind en S. (1996). Mortality of potato leafhopper adults on synthetic diets containing seven glycoalkaloids synthesized in the foliage of various Solanum species. Am. Potato J., 73: 79-88.

Schiavone A., Cullere M., De Marco M., Meneguz M., Biasato I., Bergagna S., Dezzutto D., Gai F., Dabbou S., Gasco L., Dalle Zotte A. (2017). Partial or total replacement of soybean oil by black soldier fly larvae (Hermetia illucens L.) fat in broiler diets: effect on growth performances, feed-choice, blood traits, carcass characteristics and meat quality. Ital. J. Anim. Sci., 16: 1-8.

Schiavone A., Dabbou S., De Marco M., Cullere M., Biasato I., Biasibetti E., Capucchio M.T., Bergagna S., Dezzutto D., Meneguz M., Gai F., Dalle Zot t e A., G a s c o L. (2018). Black soldier fly larva fat inclusion in finisher broiler chicken diet as an alternative fat source. Animal, 12: 2032-2039. 
Short F., Gorton P., Wis e man J., B o orman K. (1996). Determination of titanium dioxide added as an inert marker in chicken digestibility studies. Anim. Feed Sci. Tech., 59: 215-221.

S o s a D.A.T., F o g li a n o V. (2017). Potential of insect-derived ingredients for food applications. In: Insect Physiology and Ecology, Shields V.D.C. (ed.). Rijeka, InTech, pp. 215-231.

Spranghers T., Ottoboni M., Klootwijk C., Ovyn A., Deboosere S., De Meulena er B., Michiels J., Eeckhout M., De Clercq P., De S met S. (2017). Nutritional composition of black soldier fly (Hermetia illucens) prepupae reared on different organic waste substrates. J. Sci. Food Agr., 97: 2594-2600.

Spranghers T., Michiels J., Vrancx J., Ovyn A., Eeckhout M., De Clercq P., De S m e t S. (2018). Gut antimicrobial effects and nutritional value of black soldier fly (Hermetia illucens L.) prepupae for weaned piglets. Anim. Feed Sci. Tech., 235: 33-42.

St-Hilaire S., Ottoboni M., Klootwijk C., Ovyn A., Deboosere S., De Meulena er B., Michiels J., Eeckhout M., De Clercq P., De Smet S. (2007). Fish offal recycling by the black soldier fly produces a foodstuff high in omega-3 fatty acids. J. World Aquacul. Soc., 38: 309-313.

Tanch a roenrat P., Ravindran V., Z a e farian F., R a vind ran G. (2013). Influence of age on the apparent metabolisable energy and total tract apparent fat digestibility of different fat sources for broiler chickens. Anim. Feed Sci. Tech., 186: 186-192.

Timbermont L., L a n c krie t A.,D ew u 1 f J., N o 11 e t N., S c hw a r zer K.,H a e s e brouck F., Ducatelle R., Van I m merse el F. (2010). Control of Clostridium perfringens-induced necrotic enteritis in broilers by target-released butyric acid, fatty acids and essential oils. Avian Pathol., 39: 117-121.

T s c hirner M., S i m on A. (2015). Influence of different growing substrates and processing on the nutrient composition of black soldier fly larvae destined for animal feed. J. Insects Food Feed, 1: $249-259$.

Tzompa-Sosa D., Yi L., van Valenberg H., Lakemond C. (2019). Four insect oils as food ingredient: physical and chemical characterisation of insect oils obtained by an aqueous oil extraction. J. Insects Food Feed, 5: 279-292.

Woods M.J., Cullere M., Emmenes Van L., Vincenzi S., Pieterse E., Hoffman L.C., Dalle Z ot te A. (2019). Hermetia illucens larvae reared on different substrates in broiler quail diets: effect on apparent digestibility, feed-choice and growth performance. J. Insects Food Feed, 5: 89-98.

Zeiger K., Popp J., B ecker A., Hankel J., Vis scher C., Klein G., Meemken D. (2017). Lauric acid as feed additive - an approach to reducing Campylobacter spp. in broiler meat. PloS one, 12: e0175693.

Zhao X., Vázquez-Gutiérrez J.L., Johansson D.P., Landberg R., Langton M. (2016). Yellow mealworm protein for food purposes - Extraction and functional properties. PLoS One, 11: e0147791.

Z i e gle r R. (2003). Biochemie und Stoffwechsel. In: Lehrbuch der Entomologie. 2. Auflage, Spektrum Akademischer Verlag, Dettner K., Peters W. (eds.). München, Germany, pp. 75-89.

Received: 1 VII 2019

Accepted: 23 IX 2019 